\title{
Another leap forward in Japan
}

Japan, notoriously neglectful of its universities, now seems bent on rescuing them with a substantial infusion of yen for rebuilding from the education ministry.

WHo says that Japan knows better than anybody what the market wants, but is devoid of creativity? Most people, including many Japanese. They may not have heard that the Japanese education ministry (Monbusho) hopes to spend $\$ 110$ million a year (beginning next April) on the renovation of Japan's 96 universities (see Nature 353, 292; 26 September 1991). Much of the money will go to science and engineering departments. The result should be a decisive modernization of Japan's basic science. What does this mean?

Those who wish to understand Japan, and its selfcontradictions, must first grasp a simple truth: the government of the now-richest country in the world is up to its neck in debt. The explanation is twofold. In the heyday of growth in the 1960 s and early 1970 s, the government overborrowed to build expensive things such as bullet train lines, and the Japanese people are now reluctant to foot the bill by paying higher taxes.

Traditionally, they have instead put up with unreasonably low interest rates from the commercial banks, but that means of dealing with a badly balanced budget has been foreclosed by US insistence that Japan's financial markets be deregulated. Two years ago, there was a near-revolution because the government levied a sales tax of 3 per cent (compared with 17.5 per cent in compliant Britain).

Instead, more Japanese are paying old-fashioned taxes, and government receipts have been rising more quickly in recent years than any other economic indicators. (That could yet change in the wake of the recent stock market scandals and the deflation of the economic bubble.) The government may still be in the red, but the national debt is now slightly more manageable and, after years of fiscal restraint, civil servants are itching for a spending spree. So why not rebuild the universities?

There is a sense in which this is a soft option. Employing the much-needed extra technicians, maintenance and cleaning staff in chronic short supply would in the long run cost much more. A five-year splurge on new buildings (also necessary) is a more limited and also (if only just) an affordable commitment. And the benefits will be visible. Almost every overseas visitor to a Japanese university is dismayed at the abounding ostentatious evidence of neglect; some new departments, cosily supported by industrial contracts, are spick and span, but others seem not to have had the benefit of a lick of paint since the great earthquake of 1923. Renovation is long overdue, even if able people needing extra help will continue to seek election to an extra chair for the sake of the extra pairs of hands that brings, and young researchers continue to do menial tasks that would be beneath their counterparts in the West.

The scale of the proposed renovation should also be appreciated. Monbusho now spends about $\$ 666$ million a year on building new universities and research institutes. It plans to top this up with $\$ 111$ million on rebuilding. Few research administrators in the West would not be carried away by such a windfall, even if some of the funds will come from Monbusho's research budget. And in any case, Japan, being Japan, will probably contrive to win creativity as well from its new investment.

\section{US kills sex survey}

The NIH are afraid of both Congress and the Bush Administration when it comes to sex

A FEW weeks ago the US Department of Health and Human Services (HHS) vetoed a survey of sexual behaviour in teenagers that had won the approval of the National Institutes of Health. The questionnaire, the HHS Secretary said, undermined his efforts to promote abstinence. Now, the NIH themselves have backed off a survey of sexual practices among adults that had received high scores from a committee of scientific peers. The reason: NIH does not want to risk another confrontation with the Secretary, or the ire of conservative members of Congress who argue that what people do in bed is not the government's business.

In the midst of the AIDS epidemic, in which evidence points to the likelihood of an increase of virus spread among heterosexual men and women during this decade, a reluctance to learn about human sexuality in contemporary society and the circumstances that motivate people to engage in various forms of activity is just plain dangerous to the public health.

Two years ago, former British prime minister Margaret Thatcher, as narrow-minded on this subject as her American counterparts, thwarted similar studies. But British researchers succeeded despite the absence of government funding when a private foundation came to their aid. US researchers also deserve assistance from the private sector in order to gather valuable data in spite of the government. 